\title{
PENINGKATAN KEMAMPUAN BERNAVIGASI GUNA MENCEGAH TERJADINYA KECELAKAAN DALAM PELAYARAN DI KM. HOKKY VIII
}

\author{
Mohammad Shohibul Anwar ${ }^{1 *}$, Dedi Nuryaman ${ }^{1}$, Elis Suswati ${ }^{1}$ \\ ${ }^{1}$ Program Studi Nautika, Akmi Suaka Bahari Cirebon \\ Jl. Jendral Soedirman No. 156, Ciperna - Cirebon \\ *Email: Awank30may@gmail.com
}

\begin{abstract}
Abstrak
Keselamatan dalam berlayar merupakan masalah bersama dan tanggung jawab yang harus diatasi oleh semua pihak terutama yang berkecimpung di dunia pelayaran, hal ini tentunya memiliki dampak yang sangat besar terutama masalah keselamatan jiwa di laut dan kapal beserta muatannya yang sangat besar mempengaruhi kepercayaan pengguna jasa transportasi. laut. Dalam setiap pekerjaan, manusia selalu memegang peranan terpenting, dimana ketika sumber daya manusia berperan sebagai manajer, menentukan berhasil tidaknya suatu pekerjaan ditentukan oleh kegiatan manajerial yang dilakukan untuk merencanakan, mengatur, menempatkan, dan mengendalikan bawahannya untuk keberhasilannya. dari pekerjaan mereka. Begitu juga dalam dunia perkapalan dimana manusia memegang peranan yang sangat penting terutama dalam penjagaan baik pada saat berlayar maupun saat berada di pelabuhan, sehingga diatur sedemikian rupa agar kondisi manusia ini dapat tetap dalam kondisi prima untuk menjadi. mampu menjalankan tugasnya baik dalam masa tugas jaga maupun dalam masa istirahat. .Meski begitu, manusia masih menjadi penyebab utama kecelakaan pelayaran yang terjadi hingga saat ini selain penyebab lain seperti faktor alam dan teknis.
\end{abstract}

Kata kunci: Peningkatan Kemampuan, Bernavigasi, Kecelakaan Kapal.

\section{PENDAHULUAN}

Dikutip dari laman Kementrian Perhubungan Republik Indonesia (Senin, 24 Pebruari 2014) Menurut Capt. Bobby R bahwa Peningkatan kinerja keselamatan pelayaran adalah hal yang sangat penting untuk dapat diwujudkan, karena mencerminkan semangat untuk senantiasa mengedepankan pelayanan yang terbaik di bidang pelayaran.

Data Ditjen Hubla selama kurun waktu lima tahun (2008-2013), terjadi fluktuasi jumlah angka kecelakaan kapal dimana dari rentang waktu 6 tahun terdapat kecelakaan kapal sebanyak 759 kejadian. "Rata-rata terjadi penurunan jumlah kecelakaan kapal sebesar $6,95 \%$ pertahun, namun jumlah korban meninggal masih tinggi yaitu sebanyak 1180 jiwa, angka "berfluktuasi" yakni tahun 2011 meningkat sebanyak 343 jiwa, tetapi menurun pada tahun 2012 dan tahun 2013, masing-masing sejumlah 150 jiwa".

Oleh Karena itu, keselamatan pelayaran merupakan tanggung jawab bersama yang harus ditanggulangi oleh semua pihak khususnya bagi mereka yang berkecimpung di dalam dunia pelayaran, hal ini tentu memberikan dampak yang sangat besar terutama masalah keselamatan jiwa di laut serta kapal dan muatannya yang sangat mempengaruhi kepercayaan para pengguna jasa transportasi laut. Masalah ini tentunya menjadi perhatian utama para pelaku bisnis pelayaran dan International Maritime Organization (IMO) yang berkedudukan sebagai sebuah organisasi maritim internasional di bawah organasiasi dunia Perserikatan Bangsa-Bangsa (PBB).

Berbagai upaya telah dilakukan untuk menanggulangi masalah ini termasuk dengan diadakannya beberapa konvensi (baca:kesepakatan) oleh IMO tentang keselamatan dalam berlayar, termasuk dengan diberlakukannya berbagai peraturan sebagai pengaplikasian dari konvensikonvensi yang telah diadakan seperti konvensi tentang STCW pada tahun 1978 dan diamandemen tahun 1995, SOLAS 1974, Collision Regulation 1972, MARPOL 1974, International Load Line Convention 1966, yang bertujuan untuk menciptakan dunia pelayaran yang lebih aman dan laut 
menjadi lebih bersih.

Di berbagai bidang pekerjaan apapun, manusia selalu memegang peranan paling penting dimana sumber daya manusia berkedudukan sebagai manager yang membuat perencanaan, mengorganisasikan, menempatkan, dan mengendalikan anak buahnya untuk kesuksesan pekerjaannya.

Begitupun dalam dunia pelayaran dimana manusia memegang peranan sangat penting terutama dalam watchkeeping atau penjagaan baik ketika dalam sebuah pelayaran atau ketika berada di pelabuhan, sehingga diatur sedemikian rupa supaya kondisi manusia ini dapat tetap dalam kondisi prima untuk dapat menjalankan tugasnya baik dalam dinas jaga ataupun rest periodenya.

Walaupun demikian, tetap saja manusia masih menjadi penyebab utama dari kecelakaan pelayaran (Human Error) yang terjadi sampai saat ini disamping penyebabpenyebab lainnya seperti faktor alam dan faktor teknis.

Berdasarkan permasalahan di atas, maka dalam penelitian ini akan membahas tentang permasalahan bernavigasi yang baik terutama ketika cuaca buruk yang dapat mengganggu amannya suatu pelayaran dan suksesnya operasional kapal KM. HOKKY VIII.

\section{LANDASAN TEORI}

Kecelakaan Kapal menurut Kamus Besar Bahasa Indonesia (KBBI) adalah kejadian atau peristiwa yang menyebabkan orang celaka di kapal. Sebab-Sebab Kecelakaan Transportasi Laut Beberapa hal yang telah terjadi di bidang transportasi laut yang berkaitan dengan musibah dan kecelakaan kapal dan gangguan keamanan di laut/maritim, menunjukkan adanya kelemahan empat perangkat yang terlibat dalam dunia transportasi secara umum yakni perangkat keras (hardware), perangkat lunak (software), perangkat hidup (lifeware) dan perangkat organisasi (organoware). Oleh karena itu guna mendalami mengapa hal tersebut terjadi, ada dasar teori yang relevan mengupas hal tersebut, yakni: menjelaskan bahwa situasi berbahaya yang mengarah pada kecelakaan merupakan hasil dari kombinasi kegagalan teknis, manusia, dan organisasi. Dengan membuat sistem pertahanan, seperti sistem keselamatan otomatis, prosedur keselamatan standar, akan mencegah situasi ini mengarah ke timbulnya insiden dan membuat sistem akan kembali ke keadaan normalnya. Model sederhana yang menjelaskan hal itu dapat dilihat pada Gambar 2 sebagai berikut: Model Sederhana Penyebab Kecelakaan (Van der Schaaf, 1992) Penjelasan praktis yang dapat membedakan ketiga hal tersebut adalah sebagai berikut: a. Kegagalan Teknis: berhubungan dengan kegagalan atau unjuk kerja yang kurang optimal pada peralatan teknis yang digunakan selama terjadinya insiden, atau kegagalan berhubungan dengan keadaan fisik dimana insiden terjadi. Kegagalan teknis merupakan wilayah kerja dari para desainer dan insinyur serta kemungkinan sebagai penjelasan yang mudah dipahami sebagai penyebab kecelakaan. Tetapi, sebagai penjelasan yang mudah dipahami bukan berarti secara otomatis sebagai bagian yang mudah dikendalikan. Berdasarkan temuan yang didapati dalam investigasi suatu kecelakaan, perbaikan pada sistem dapat mengurangi kegagalan dengan penyebab yang serupa. Fokus pada perbaikan teknis dapat dilihat dari jumlah insinyur yang bekerja di organisasi berada. Insinyur desain dan perawatan merupakan bagian yang penting dari suatu organisasi, bertanggung jawab untuk memelihara dan memperbaiki keandalan dari sistem teknik. Secara bersama-sama mereka menyediakan pengetahuan dengan dasar teknik (technical knowledge based) pada organisasi. b. Kegagalan Manusia: berhubungan dengan kesalahan yang dibuat manusia sebagai pertahanan terakhir dari sistem pertahanan, berhubungan langsung sebagai pemicu terjadinya insiden. Manusia selalu memiliki kecenderungan untuk melakukan kesalahan. Selama beberapa dekade, para peneliti khususnya bidang psikologi mencari penyebab bagaimana dan mengapa manusia 
melakukan kesalahan. Dari beberapa model kebiasaan manusia, model yang cukup terkenal adalah model Rasmussen "s Skill-, Rule-, and Knowledge-based behaviour (1976). Rasmussen membedakan ketiga tingkatan kebiasaan manusia tersebut yang berhubungan secara hirarki sebagai berikut: - Kebiasaan berdasarkan keterampilan: mengarah pada tugas rutin, membutuhkan sedikit atau tidak sama sekali perhatian dalam menjalankan tugas tersebut. Kebiasaan berdasarkan aturan: mengarah pada prosedur yang telah dikenal untuk digunakan dalam situasi pengambilan keputusan. - Kebiasaan berdasarkan pengetahuan: mengarah pada aktivitas untuk memecahkan masalah. Langkah penting lainnya, untuk menjelaskan kesalahan manusia adalah membedakan slips dan mistakes. Slips adalah bentuk kesalahan yang dilakukan pada suatu rencana yang sesuai. Sedangkan mistakes adalah bentuk kesalahan dimana terjadi karena rencana yang tidak sesuai, hal ini berawal dari fase perencanaan. Reason (1987) mengkombinasikan model Rasmussen "s SRK dan perbedaan antara slips dan mistakes dalam Generic Error-Modelling System (GEMS). Technical failure Human operator failure Organizational failure Dangerous situation Return to normal Adequate defences Developing incident Near miss Adequate (human) Accident Vol. 06, No. 2 Sebuah Analisis Tentang Sebabsebab Kejadian Kecelakaan KM. Putri Ayu 159 c. Kegagalan Organisasi: berhubungan dengan kesalahan yang dibuat organisasi sebagai pertahanan awal dari sistem pertahanan, tidak berhubungan langsung dengan terjadinya insiden secara langsung tetapi merupakan pemicu yang membawa kegagalan lain menuju insiden. Langkah yang paling penting dalam menjelaskan kegagalan organisasi adalah membedakan antara kegagalan aktif dan kegagalan laten. Kegagalan aktif merupakan kegagalan dengan ciri efek dari kegagalan dirasakan sangat cepat. Kegagalan laten merupakan kegagalan dimana efek yang ada dirasakan dalam waktu yang lama dan baru sangat terasa bila berkombinasi dengan faktor lain yang dapat menerobos semua sistem pertahanan yang ada (Reason, 1990). Dampak Kecelakaan Transportasi Laut Kecelakaan transportasi laut dapat berakibat luas, yaitu: - Menimbulkan korban jiwa yang tak ternilai. - Menyebabkan gangguan psikologi bagi korban. - Menimbulkan kerugian material, dan - Menyebabkan kerusakkan lingkungan

\section{Pengertian Bernavigasi}

Menurut Supriyono (2000), Bernavigasi merupakan proses mengarahkan gerak kapal dari satu tempat ke tempat yang lain dengan aman dan lancar serta untuk menghindari bahaya atau rintangan pelayaran. Istilah navigasi sendiri berasal dari bahasa Yunani yang terdiri dari kata Navis yang artinya perahu atau kapal dan Agake yang artinya mengarahkan. Secara harfiah artinya mengarahkan sebuah kapal dalam pelayaran

Telah dilakukannya penelitian yang sama seperti masalah yang penulis angkat, ini dapat dilihat dari terbitan buku-buku yang membahas tentang bagaimana cara bernavigasi jika menghadapi cuaca buruk, seperti: COLREG Rule 19 Conduct Of Vessel In Restricted Visibility.

Dalam sebuah pelayaran, Nahkoda sebagai Mualim paling senior, tentunya akan lebih mengetahui dan lebih bisa mengidentifikasi apabila akan terjadi cuaca buruk terutama pada awal bulan September sampai dengan awal Maret yang biasanya cuaca buruk pada waktu tersebut sering terjadi, seperti yang dikemukakan dalam Ilmu Cuaca untuk (PLAP,1986:87)

Nahkoda sebagai pimpinan tertinggi di atas kapal juga harus menetapkan beberapa kebijakan untuk diperhatikan oleh bawahannya untuk dilaksanakan yang masih termasuk dalam tahap persiapan ketika berlayar. Dalam musim penghujan dimana rawan akan terjadinya cuaca buruk, seperti yang diuraikan dalam IMARE (Ketentuan ILO Mengenai: Pencegahan Kecelakaan Di Atas Kapal Laut Dan Di Pelabuhan) IMARE/BAB 20/ Rev.00. (ILO,2000:8). 
Perwira yang berdinas jaga harus mengambil tindakan jika mengetahui adanya tanda-tanda cuaca buruk seperti yang dikemukakan dalam Meteorologi dan Oceanografi untuk Pelayaran (Direktorat Jenderal Perhubungan Laut, 1986:8.29).

Perwira jaga juga harus melaporkan tentang keadaan disekitar dan pengaruhnya terhadap navigasi dan mencatatnya dalam log book sebagai pertanggungjawaban atas jam jaganya yang kemudian dilaporkan ketika melakukan serah terima jaga, seperti yang dijelaskan dalam Program Pemutakhiran (Updating) dari STCW 1978 Amandement 1995 tentang "Watch Keeping Deck” Dinas Jaga 2001. (IMO,2001:5).

Sekali ditentukan adanya cuaca buruk, tindakan berikutnya adalah menentukan dimana pusatnya berada untuk mengusahakan agar berada sejauh mungkin dari padanya. Sesegera mungkin melalui radio, sesuai artikel 35 dari Interntional Convention for the Safety of live at sea (1974) dikirimkan berita keamanan tertuju kepada stasiun radio pantai terdekat dan semua kapal disekitarnya. Selama kapal dibawah pengaruh badai diharapkan, tetapi tidak diharuskan, mengadakan pengamatan tiap jam dan mengirimkannya.

Definisi

Secara umum, banyak kosa kata yang perlu dijelaskan mengenai penulisan ini. Tetapi karena luasnya ruang lingkup serta keterbatasan ilmu pengetahuan yang dimiliki dan dikuasai penulis. Maka berikut beberapa definisi pembahasan dari penulisan ini

\section{Pengertian Cuaca}

Cuaca adalah keadaan udara pada saat tertentu dan di wilayah tertentu yang relatif sempit (tidak luas) dan pada jangka waktu yang singkat. Atau definisi cuaca ialah keadaan udara harian pada suatu tempat tertentu dan meliputi wilayah yang sempit, keadaan cuaca ini dapat berubah setiap harinya.

Atau pengertian cuaca yang lainnya yaitu suatu keadaan rata-rata udara seharihari disuatu tempat tertentu \& meliputi wilayah yang sempit dalam jangka waktu yang singkat. Keadaan dari cuaca mudah berubah - ubah, karena disebabkan oleh tekanan udara, suhu, angin, kelembaban udara, dan juga curah hujan. Berikut hal-hal yang mempengaruhi cuaca :

a. Suhu atau Temperatur

Suhu / Temperatur adalah suatu besaran yang menunjukan derajat panas dinginnya dari suatu benda. Adanya perbedaan tingkat pemanasan matahari di permukaan bumi, menyebabkan suatu kawasan akan memiliki perbedaan suhu dengan kawasan lainnya. Sebagian panas yang sampai ke permukaan bumi diserap dan sebagian lagi dipantulkan. Pantulan sinar matahari tersebut akan sangat memengaruhi suhu di kawasan tersebut.

b. Kelembapan Udara

Pengertian kelembapan udara adalah kandungan uap yang ada dalam udara. Pemanasan yang terjadi pada permukaan bumi menyebabkan air-air yang ada pada permukaan bumi, baik di daratan maupun lautan, menguap dan termuat dalam udara. Kelembapan udara dapat berubahubah, tergantung pada pemanasan yang terjadi. Makin tinggi suhu di suatu kawasan, maka makin tinggi pula tingkat kelembapan udara di kawasan tersebut, karena udara yang mengalami pemanasan, merenggang dan terisi oleh uap air.

Kandungan uap air yang termuat dalam jumlah udara tertentu pada temperatur tertentu dibandingkan dengan kandungan uap yang dapat termuat dalam udara tersebut disebut kelembapan relatif atau nisbi.

c. Tekanan Udara

Tekanan udara adalah suatu gaya yang timbul oleh adanya berat dari lapisan udara. Udara merupakan kumpulan gas yang masing-masing memiliki massa dan menempati ruang. Karena massa yang dimilikinya, udara pun memiliki tekanan. Suhu di suatu kawasan sangat berpengaruh terhadap tekanan udara di kawasan tersebut. Bila suhu makin tinggi, maka tekanan udara akan makin rendah. Ini disebabkan udara 
yang hangat bersifat renggang. Sebaliknya, bila suhu makin rendah, maka tekanan udara akan makin tinggi karena udara yang dingin lebih padat daripada udara yang panas. Berdasarkan hal tersebut, suhu sangat menentukan perbedaan tekanan udara di setiap kawasan di muka bumi ini.

d. Angin

Angin adalah udara yang bergerak. Seperti telah kita ketahui, tekanan udara di setiap kawasan di bumi ini tidak sama. Karena adanya perbedaan tekanan udara di dua kawasan yang berbeda, maka udara yang berada di salah satu kawasan tersebut akan bergerak di kawasan lain. Udara akan bergerak dari daerah dengan tekanan udara tinggi ke daerah dengan tekanan yang lebih rendah untuk mengisi ruang. Maka udara bergerak dari daerah yang dingin ke daerah yang lebih panas

e. Curah Hujan

Pengertian curah hujan adalah ketinggian air hujan yang terkumpul dalam tempat yang datar, tidak menguap, tidak meresap, dan tidak mengalir. Hujan ialah suatu proses jatuhnya air $(\mathrm{H} 2 \mathrm{O})$ dari udara ke permukaan bumi. Air yang jatuh dapat berbentuk cair maupun padat (es dan salju). Hujan terjadi karena menguapnya air sebagai akibat dari pemanasan sinar matahari. Uap-uap air tersebut kemudian naik ke atmosfer dan mengalami kondensasi sehingga membentuk awan. Lama-kelamaan, awan akan makin berat, karena kandungan airnya makin banyak. Bila uap air di awan telah mencapai jumlah tertentu, maka titik-titik air pada awan tersebut akan jatuh sebagai hujan.

f. Awan

Awan adalah kumpulan besar dari titik-titik air atau kristalkristal es yang halus di atmosfer. Pada waktu musim kemarau sedikit sekali kita jumpai awan di udara karena penguapan yang terjadi sedikit, akan tetapi di musim hujan kita dapat menjumpai banyak sekali awan dengan berbagai bentuk dan variasinya, hal ini karena kandungan uap air di udara cukup banyak. Berdasarkan bentuknya, awan dibagi sebagai berikut.

Awan cumulus, yaitu awan putih yang bergerombol yang sering kita lihat di siang dan sore hari. Awan stratus, yaitu awan yang berbentuk seperti selimut yang berlapis-lapis dan relatif luas.Awan cirrus, yaitu awan yang letaknya tinggi sekali dan tipis seperti tabir. Awan nimbus, yaitu awan gelap dengan bentuk yang tidak menentu, awan ini menandakan akan terjadinya hujan.

\section{Pengertian kapal}

Kapal adalah semua alat berlayar, apapun nama dan sifatnya termasuk didalamnya adalah kapal karam, mesin pengeruk lumpur, mesin penyedot pasir dan alat pengangkut terapung lainnya. Meskipun benda-benda tersebut tidak dapat bergerak dengan kekuatannya sendiri, namun dapat digolongkan ke dalam "alat berlayar" karena dapat terapung/mengapung dan bergerak di air. (KUHD pasal 309 ayat 1).

Kapal adalah kendaraan air dengan bentuk dan jenis tertentu yang digerakkan dengan tenaga angin, tenaga mekanik, energi lainnya, ditarik atau ditunda, termasuk kendaraan yang berdaya dukung dinamis, kendaraan di bawah permukaan air, serta alat apung dan bangunan terapung yang tidak berpindah-pindah. (Undang-Undang No. 17 tahun 2008 tentang Pelayaran).

\section{Pengertian Pelayaran}

Pelayaran merupakan sarana yang penting untuk menjaga keselamatan berlayar bagi berbagai macam kapal. Di bidang ekonomi, pelayaran masih diperlakukan sebagai industri penunjang. Tak ada perlakuan khusus, sebagaimana diterapkan oleh negara-negara maju. Kemudian, bentuk-bentuk conference yang dicoba diterapkan di lingkungan pelayaran masih ditafsirkan sekalangan ekonom Indonesia sebagai bentuk kartel atau monopoli ekonomi.

\section{Pengertian Navigasi}

Istilah navigasi sendiri dipakai untuk merujuk pada proses estimasi berbasis kinematik vehicle state (posisi, kecepatan, dan attitude) secara realtime sebagai acuan 
untuk menentukan pergerakan kendaraan sepanjang lintasan pergerakan. Vehicle state berguna untuk kontrol otomatis, realtime planning, data logging, Simultaneous Location and Mapping (SLAM), atau komunikasi operator yang dipakai pada navigasi. Navigasi sering digunakan untuk memandu suatu objek, baik manusia, kendaraan maupun robot, untuk melewati suatu daerah yang belum dikenali sebelumnya. Merujuk pada banyak literature tentang autonomous vehicle menyebutkan bahwa navigasi terbagi menjadi dua pengertian. Penentuan secara akurat kondisi/keberadaan kendaraan vehicle state, antara lain posisi, kecepatan, dan sikap attitude nya. Merencanakan dan melaksanakan gerakan yang tepat yang berguna untuk perpindahan menuju lokasi yang diinginkan (https://paralegal.id/ pengertian/navigasi/)

\section{METODE}

Jenis penelitian ini yaitu penelitian kualitatif. Lexy J. Moleong (2010) menjelaskan penelitian kualitatif adalah penelitian yang bermaksud untuk memahami fenomena tentang apa yang dialami oleh subjek penelitian, misalnya perilaku, persepsi, motivasi, tindakan, dan lain-lain, secara holistic, dan dengan cara deskripsi dalam bentuk kata-kata dan bahasa, pada suatu konteks khusus yang alamiah dan dengan memanfaatkan berbagai metode alamiah.

\section{Teknik Pengumpulan Data}

Teknik pengumpulan data yang digunakan dalam penelitian ini didasarkan pada fakta dan informasi yang diperoleh di atas kapal, ditambah sumber dari buku-buku mengenai permasalahan yang dibahas dalam karya tulis ini yang dapat dijadikan sebagai acuan penyusunan penelitian. Pengumpulan data juga dilakukan melalui bertanya kepada para awak apal yang bekerja di atas kapal. Adapun teknik pengumpulan data yang digunakan dalam penelitian ini adalah:

\section{a. Observasi}

Observasi dilakukan tidak hanya mencatat suatu kejadian atau peristiwa yang diamati, akan tetapi segala kejadian yang diduga berkaiatan dengan masalah yang diteliti. Data penelitian diambil pada saat pengamatan kegiatan berlangsung.

\section{b. Wawancara}

Wawancara dilakukan secara terstruktur, dimana pewawancara yang menetapkan sendiri masalah dan pertanyaan-pertanyaan yang akan diajukan. Sehingga, jawaban yang disampaikan oleh responden sesuai dengan pertanyaan-pertanyaan yang peneliti sampaikan. Dari wawancara tersebut, diharapkan dapat diperoleh data-data dan informasi secara mendalam. Selain melakukan observasi terhadap objek penelitian di lapangan secara langsung, peneliti juga melakukan wawancara secara spontan dengan Crew Kapal KM. HOKKY VIII.

\section{c. Dokumentasi}

Menurut Lexy J.Moleong (2010) yang dimaksud dengan dokumen adalah bahan tertulis, seperti data-data perkapalan dan dokumen yang berkaitan cara bernavigasi yang baik serta data yang mendukung dengan penelitian.

\section{HASIL DAN PEMBAHASAN}

Ada beberapa hal dalam meningkatkan kemampuan bernavigasi guna mencegah terjadinya kecelakaan dalam pelayaran dikapal, diantaranya:

\section{Mencari tahu keadaan cuaca}

Sebelum memulai pelayaran, ada baiknya mualim mencari tau terlebih dahulu tentang keadaan cuaca disekitar medan yang akan dilalui.apabila diketahui cuaca menunjukan adanya pembentukan awan nimbus yang berdekatan dengan posisi kapal maka Nahkoda harus diberi tahu, karena dapat membahayakan proses pelayaran.

Dengan demikian, jika terdapat penyimpangan tekanan udara sampai turun jauh dibawah normalnya maka hal ini menandakan adanya sebuah siklon tropika yang mendekati posisi kapal. Sesuai dengan teori di atas, tindakan yang harus dilakukan 
adalah melakukan pengecekan berkala dengan frequensi sesering mungkin untuk melihat tekanan udara pada penunjukan barometer sehingga dapat diketahui apabila terjadi penurunan tekanan yang jauh dari normal segera lakukan tindakan untuk mengantisipasi datangnya awan nimbus untuk dilaporkan kepada Nahkoda.

2. Selalu memperhatikan muatan dan stabilitas kapal

Dalam perjalanan dengan cuaca buruk dan kondisi laut yang membahayakan serta stabilitas kapal yang mengkhawatirkan, Perwira jaga harus memerintahkan seseorang untuk memeriksa kondisi temperatur reefer container dengan memperhatikan keselamatannya. Seharusnya tidak seorang pun awak kapal diperbolehkan berada di deck ketika cuaca buruk, kecuali keadaan mendesak. Setiap orang yang ditugaskan di deck pada saat cuaca buruk diwajibkan memakai rompi penyelamat atau life jacket dan dilengkapi dengan radio serta terus melakukan hubungan dengan anjungan dan bila perlu didampingi oleh back up persons yang selalu memantaunya serta mengenakan pakaian yang terang (reflective colour). Awak kapal yang ditugaskan ini haruslah yang paling berpengalaman dan bekerja berpasangan serta dalam pengawasan dan dibawah pimpinan Perwira senior yang berpengalaman pula.

Dilain keadaan itu ketika diterima berita cuaca buruk akan terjadi, Mualim 1 sebagai Perwira yang bertanggung jawab terhadap masalah muatan seharusnya melakukan pengamanan yang lebih kuat terhadap muatan yang dibawanya, tali-tali penyelamat harus dipasang di tempat-tempat yang diperlukan sebagai tindakan antisipasi, dan semua pengikatan muatan deck terutama pengikatan untuk kapal jenis kontainer harus diperiksa dan dikencangkan sebagai tindakan antisipasi sebelum terjadinya cuaca buruk, jika perlu pekerjaan di deck pada saat cuaca buruk harus dengan seizin Nahkoda dan dengan sepengetahuan Perwira jaga di anjungan.

Apabila hal di atas dilakukan sesuai prosedur yang berlaku, tentunya ketika cuaca buruk terjadi semua pengikatan pada kontainer dalam kondisi yang baik sehingga tidak akan terjadi pengikatan kendur yang akan mengakibatkan kontainer jatuh ke atas deck ataupun jatuh ke laut.

3. Mengamati dan melaporkan

Setelah menerima pemberitaan mengenai cuaca dari weather facsimille dan navtex juga himbauan-himbauan atau peringatan yang diberikan oleh stasiun pantai atau Marine Departement setempat pada deskripsi data, ada baiknya Nahkoda mempelajari terlebih dahulu berita tersebut dan melakukan banyak pertimbangan tentang kondisi perairan, kapal dan muatannya serta waktu yang telah ditetapkan sebelum akhirnya mengambil keputusan.

Setiap Nahkoda dari setiap kapal yang ketika bernavigasi bertemu dengan cuaca buruk seperti es, badai tropis, angin dengan kecepatan 7 pada Skala Beaufort atau lebih atau bahaya navigasi lain yang dapat membahayakan palayaran harus mengirimkan berita bahaya kepada semua kapal dalam jangkauan dan mengadakan komunikasi dengan mereka.

Pengiriman berita bahaya juga harus dengan ketentuan, yaitu :

a. Posisi dimana kapal berada, diarea mana kita berlayar dan berapa jauh dari garis pantai, sesuai dengan ketentuan pembagian area-area perairan yang terbagi kedalam area A1 sampai A4.

b. Peralatan yang harus digunakan untuk pengirman berita dalam area tersebut INMARSAT A, INMARSAT B, atau IMMARSAT C.

c. Prosedur yang harus dilakukan dalam pengiriman berita bahaya, sesuai dengan ketentuan dalam GMDSS yaitu:

1) Tekan tombol Distress untuk memulai panggilan.

2) Pilih gelombang dimana seharusnya berita Distress dikirimkan pada $V H F$, $M F, I N M A R S A T$, atau $H F$.

3) Radio harus dinyalakan pada gelombang Distress DSC yang dipilih DSC, jika otomatis maka DSC akan memilih 
sendiri gelombangnya, akan tetapi jika tidak harus dilakukan secara manual.

4) Jika waktu mengijinkan, pilih pada layar menu jenis kejadian, posisi kapal (jika tidak otomatis dari GPS), dan waktu UTC ketika itu.Jika waktu mengijinkan pilih jenis kejadian Distress yang di alami seperti: grounding, abandon ship, fire on board, piracy attack dan sebagainya sesuai yang terjadi di kapal anda.

5) Pilih jenis komunikasi yang di inginkan, dengan suara atau Telex dan frequensi yang digunakan.

6) Kirim berita Distress tadi dengan menekan dua kali tombol Distress atau tombol lain (jika jenis alatnya berbeda).

7) Mempersiapkan untuk saluran yang dipilih dengan menyalakan radio pada gelombang yang digunakan pada gelombang yang digunakan untuk mengiirim berita dan menunggu persetujuan dari kapal lain atau stasiun pantai setempat.

8) Memperhatikan alat keselamatan

Sebelum cuaca buruk terjadi, seharusnya Mualim 3 sebagai Perwira yang bertanggung jawab terhadap alat-alat keselamatan sebaiknya melakukan tindakan penyelamatan atau pengamanan yang lebih terhadap peralatannya yaitu dengan menyimpan di dalam perlengkapan milik bosun untuk sementara waktu sampai cuaca reda. apabila tindakan ini dilakukan mungkin tidak akan ada life bouy yang hanyut terhempas ombak atau rusak paling tidak bisa mengurangi jumlah kerugian yang akan diderita.

Solusi dalam permasalahan dalam bernavigasi ketika cuaca buruk, yaitu:

1. Mengadakan briefing atau pengarahan terhadap para Perwira kapal

Dalam masalah bernavigasi yang baik terutama sebelum berlayar memasuki daerah cuaca buruk dalam mengidentifikasi keadaan disekitarnya terhadap kemungkinan terjadinya resiko terburuk yang akan terjadi dengan mempertimbangkan semua indikator suhu, tekanan udara, kecepatan dan arah angin, kondisi laut dan arusnya, kabut dan awan serta kemungkinan adanya bongkahan es yang terseret yang bisa membahayakan.

Keuntungannya, pengarahan yang dilakukan seperti ini akan memakan waktu yang singkat dan setiap Perwira kapal akan memahami dan mengetahui semua teknik yang harus dilakukan dalam bernavigasi termasuk ketika cuaca buruk berlangsung mulai dari identiikasi, bagaimana tindakan antisipai yang harus dilakukan seperti mengamankan muatan dan alat-alat keselamatan, cara berkomunikasi yang baik dengan menggunakan peralatan bantu navigasi yang standar, dan kebijakan apa saja yang harus diambil ketika bernavigasi memasuki perairan dengan cuaca buruk baik dalam bermanuver dan komunikasi dengan radio pantai sehingga bisa menghindari resiko terburuk dari kejadian tersebut.

Kerugiannya, apabila kita mengambil alternatif di atas, untuk melaksanakan sebuah penyuluhan tentunya diperlukan waktu bagi Nahkoda untuk mengupulkan semua Perwira misalnya sewaktu sandar dipelabuhan dan menyita waktu untuk para Perwira melakukan persiapan sebelum melakukan pelayaran terutama untuk Mualim 2 yang harus menyiapkan peta dan peralatan bantu navigasi lainnya untuk pelayaran berikutnya.

2. Nahkoda mengadakan pengawasan langsung atau berada di anjungan

Kegiatan ini dilakukan untuk mengambil alih semua pimpinan dibawah perintahnya sehingga sebelum kejadian yang buruk terjadi, Nahkoda bisa megantisipasinya dengan mengadakan beberapa tindakan baik untuk para pekerja dek dan muatannya juga untuk permasalahan dalam bernavigasi dan komunikasi yang diperlukan ketika cuaca buruk terjadi, sehingga semua tindakan ragu-ragu yang mungkin akan dilakukan oleh para Perwira jaga dapat dihindari dan kecelakaan pelayaran dapat dihindari.

Keuntungannya, dengan dilakukan pengawasan langsung terhadap semua kegiatan selama pelayaran dalam cuaca 
buruk maka Nahkoda bisa mengontrol semua kegiatan dan mengoreksi secara langsung tindakan dari para Perwira kapal yang membahayakan kapal sehingga resiko terburuk dapat dihindari karena semua pembacaan berita cuaca, komunikasi dan perintah untuk tindakan antisipasi langsung dilakukan Nahkoda sebagai Perwira yang paling berpangalaman sehingga dapat mengatasi permasalahan yang ada dengan tindakan antisipasi yang lebih dini.

Kerugiannya, cuaca buruk dalam musim penghujan atau sekitar bulan September sampai Maret bisa berlangsung selama pelayaran yang akan memakan waktu yang lama sehingga sangat tidak memungkinkan bagi Nahkoda untuk selalu berada di anjungan selama itu mengingat rest periode yang diperlukan oleh setiap awak kapal, disamping itu tugas khusus Nahkoda yang lainnya dan tentunya lebih penting yang tidak dapat diabaikan hanya untuk mengatasi situasi ini.

3. Nahkoda melakukan pemeriksaan kapal sebelum memulai palayaran

Nahkoda harus memastikan semua alat-alat keselamatan dan semuanya dalam kondisi yang aman untuk melakukan sebuah pelayaran memasuki cuaca buruk, sehingga ketika kapal berlayar pengikatan pada muatan dan alat-alat keselamatan dapat bertahan sampai kapal tiba di pelabuhan tujuan dengan selamat.

Keuntungannya, Dengan mengambil alternatif ini dapat dipastikan semua kondisi pengikatan baik pada muatan dan alat-alat keselamatan dalam kondisi baik, sehingga tidak akan terjadi pengikatan yang kendur atau alat-alat keselamatan yang jatuh kelaut.

Kerugiannya, Pada alternatif ini Nahkoda dituntut untuk dapat memberikan waktu lebih untuk melakukan pemeriksaan terhadap semuanya sementara tugas Nahkoda dipelabuhan sangat banyak untuk mengurus semua clearance baik untuk awak kapal, kapal, dan muatannya sehingga kemungkinan urusan dengan Agent dan pihak pelabuhan akan terbengkalai.

4. Nahkoda memberikan sebuah catatan

Catatan ini merupakan sebuah rangkuman dari petunjuk untuk bernavigasi mulai dari persiapan, termasuk channel radio yang digunakan, penggunaan bahasa dalam komunikasi, identifikasi, maneuver, dan sebagainya yang merupakan rangkuman dari publikasi navigasi yang dikemas dengan gaya tersendiri yang lebih sederhana dan menarik supaya mudah dipelajari untuk memperjelas tindakan yang harus dilakukan sebagai antisipasi atau menghindari resiko terburuk ketika cuaca buruk berlangsung dan memerintahkan semua Perwira jaga untuk memanggil Nahkoda, setiap kali timbul keraguan untuk mengambil tindakan dalam bermanuver, berkomunikasi, atau dalam pembacaan berita navigasi seperti weather facsimile, atau untuk memutuskan pekerjaan yang harus dilakukan bagi para pekerja harian dan yang lainnya sehingga kecelakaan pelayaran dapat dihindari dan kegiatan operasional kapal akan berjalan dengan lancar.

Keuntungannya, pada alternatif ini pembagian jaga teratur sebagaimana mestinya sehingga tidak ada salah satu pihak yang dirugikan dan diuntungkan, disamping itu Nahkoda sebagai penganggung jawab utama juga bisa melakukan pengawasan secara acak ketika waktu-waktu tertentu sesuai dengan perhitungan yang dibuat dimana cuaca pada saat itu bisa membahayakan, selain itu apabila terdapat kesalahan perhitungan oleh Nahkoda, Perwira jaga dapat memanggil Nahkoda pada saat-saat yang menimbulkan keraguraguan untuk mengambil tindakan, sehingga tidak terjadi kesalahan dalam pengambilan keputusan dan dapat dilakukan tindakan pencegahan lebih awal.

Kerugiannya, apabila terjadi kepanikan yang mungkin akan membuat Perwira kapal melakukan tindakan dengan segera dapat terjadi dikarenakan Nahkoda kapal yang seharusnya bisa dihubungi tidak berada ditempat atau sedang ketiduran, sehingga dapat menimbulkan akibat yang buruk, dan juga pihak perusahaan harus mengeluarkan biaya untuk penerbitan buku rangkuman navigasi ini. 


\section{KESIMPULAN}

Keselamatan dalam pelayaran adalah syarat mutlak untuk menjamin seluruh operasional kapal berjalan dengan baik, serta sedapat mungkin untuk menghindari kecelakaan karena kecelakaan pelayaran merupakan suatu hal yang sangat tidak diinginkan oleh pihak manapun. Kecelakaan pelayaran yang terjadi belakangan ini sering disebabkan oleh faktor alam dan faktor manusia. Pada pembahasan sebelumnya telah dilakukan analisa terhadap persoalan yang ada dan dari hasil analisa tersebut diperoleh beberapa metode sebagai alternatif pemacahan masalah.

Setelah melakukan peninjauan ulang terhadap semua permasalahan yang ada dan melihat dari keunggulan masing-masing alternatif maka diperoleh sebuah kesimpulan yaitu dengan mengambil sebuah alternatif terbaik dari masing-masing alternatif pada permasalahan yang ada sebagai metode yang akan digunakan untuk memecahkan permasalahan yang telah dan pada sub bab ini disimpulkan kesimpulan dari masalah tersebut yaitu:

1. Meningkatkan kemampuan Perwira kapal dalam mengidentifikasi cuaca buruk, mengoperasikan peralatan bantu navigasi, melakukan tindakan antisipasi sebelum melakukan pelayaran sehingga kecelakaan dalam pelayaran dapat terhindarkan.

2. Meningkatkan kesadaran Perwira kapal untuk melaksanakan tugasnya dengan penuh tanggung jawab sehingga tidak ada lagi pekerjaan yang terbengkalai.

\section{DAFTAR PUSTAKA}

Anonim, 1972, Convention on the International

Anonoim, 1974, International Convention for the Safety of live at sea,

Anonim, 2001, STCW 1978 Amandement. "Watch Keeping Deck"

Regulation for Preventing Collisions at sea (COLREG), Rule 19 Conduct Of Vessel In Restricted Visibility

Direktorat Jendral Perhubungan Laut, 1986, Meteorologi dan Oceongrafi Untuk Pelayaran

Ikatan Marine Enginer (IMARE), Ketentuan ILO Mengenai : Pencegahan Kecelakaan di Atas Kapal Laut dan Dipelabuhan.

Meleong, Lexy J., 2010, Metodologi Penelitian Kualitatif, Remaja Rosdakarya, Bandung.

International Maritime Organization, 1996, Standad Training for Certification and Watchkeeping, London.

International Maritime Organization, 2009, Safety of life at Sea 1974 amandemen 2009, London

Biro Komunikasi dan Informasi Publik, 2014, http://dephub.go.id/post/read/ kinerja-keselamatan-pelayarancermin-peningkatan-pelayanan60470?language $=\mathrm{id}$ diakses pada Sabtu 27 Maret 2021.

Supriyono, 2000, Bernavigasi Dengan Aman dan Efisien 